\title{
Delayed Development of Song Control Nuclei in the Zebra Finch is Related to Behavioral Development
}

\author{
KATHRIN HERRMANN AND HANS-JOACHIM BISCHOF \\ Universitat Bielefeld, Fakultat Biologie, Verhaltensphysiologie Postfach 8640, 4800 \\ Bielefeld 1, West Germany
}

\begin{abstract}
The postnatal development of two visual areas (nucleus rotundus and ectostriatum) and two song control areas (hyperstriatum ventrale pars caudale, HVc, and nucleus robustus archistriatalis, RA) of the zebra finch brain was followed from birth to adulthood. The following parameters were investigated: (1) neuron size, (2) volume of the brain nuclei, and (3) myelination of axons. The nucleus rotundus, the diencephalic station of the tectofugal pathway, exhibits the fastest development: rotundal neurons reach their maximum size at 20 days of age; the volume of this structure reaches adult size at the same time. The process of myelination begins between day 5 and day 10 and is completed at 40 days of age. A similar temporal sequence of development is seen in the ectostriatum, except myelination starts some days later. Thus the development of these visual areas is completed at 40 days. In contrast, the development of the song control nuclei is delayed. Neurons in RA and HVc grow steadily up to 40 days of age, attaining a size larger than that observed in adults. Whereas the volume of HVc increases until day 40 and remains stable thereafter, RA volume increases until day 70 and evidences a decrease thereafter. It is not until postnatal day 20 (RA) and day 40 (HVc) that the myelination process starts in the song control areas. Adult myelin density is achieved by 70 days in RA and by 100 days in HVc. It can be demonstrated that the development of the visual system parallels the development of visual performance of the birds. Delayed growth of song control nuclei coincides with development of song.
\end{abstract}

Key words: ontogeny, visual system, song control system, behavior

It is generally accepted that in young animals the development of behavior and that of the central nervous system are correlated in time. Not much evidence is available concerning the question of whether this temporal correlation may be more specific in the sense that, for example, visually controlled behavior develops simultaneously with the development of the visual system and, in the same species the development of a motor pattern, such as song, is correlated with the growth of the motor control system. Evidence of this kind would strengthen the idea that a temporal coincidence of behavioral and neuronal development is causal instead of incidental.

We chose the zebra finch for our studies, because, like other altricial birds, much of the neural and behavioral development occurs after hatching. Moreover, many aspects of behavioral, anatomical, and hormonal development of this bird are already known (Immelmann, '69a,b; Sossinka, '70; Pröve, '83). As our intention was to look for correlations between neuronal and behavioral development, we concen- trated on two systems that are both ethologically and anatomically well investigated, namely, the visual and the song control systems. A recent ethological study of the ontogeny of visual function in zebra finches (Bischof and Lassek, '85) suggests that young birds do not react to visual stimuli before day 10 , although their eyes open between day 5 and day 7 . From day 15 onward the birds are able to discriminate between their parents and stuffed dummies. Having this knowledge, we investigated the ontogeny of two visual areas, the nucleus rotundus of the thalamus and the telencephalic ectostriatum. Both areas are anatomically well-established stations of the tectofugal pathway in birds (Karten and Revzin, '66; Karten and Hodos, '70; Benowitz and Karten, '76; Nixdorf and Bischof, '82). This projection was chosen because in zebra finches as in other

Accepted October 31, 1985 
birds with panoramic vision this pathway is more prominent than the thalamofugal one. The latter, in turn, gains more importance in birds with large binocular fields (Pettigrew, '77).

The ontogeny and theory of song learning have been wellknown for many years (Konishi, '65; Thorpe, '58; Kroodsma, '81; Immelmann, '69a). As in other oscine birds song learning in zebra finches consists of two phases: a sensory and a sensory-motor phase. During a sensitive period, which lasts until day 35, young birds memorize song elements, preferably from their father (Böhner, '83), and store them as a template (Konishi, '65). Within a second period, the sensory-motor phase, lasting from day 35 to day 70 or 80 , birds reproduce song by trying to match their vocal output to the previously stored template. The song system of zebra finches consists of a chain of telencephalic, thalamic, and mid- and hindbrain areas (Nottebohm et al., '76; Nottebohm, '80). We followed the development of the HVc (hyperstriatum ventrale pars caudale) and the RA (nucleus robustus archistriatalis), whose function in adult song control has been examined in a series of studies (Nottebohm et al., '76; Nottebohm, '80). Their role in song learning, however, is not clear (Bottjer et al., '84). Normal development of these nuclei has not been studied previously.

For this investigation we chose three morphological indices of maturation: neuron size, total volume, and myelination of each given brain area. The volume of a brain structure as well as the size of single neurons are often suggested to be related to function. The sexual dimorphism of the song control areas (Nottebohm and Arnold, '76) and various deprivation studies concerning the mammalian visual system (Guillery, '72; Guillery and Stelzer, '70) provide evidence for this interpretation. Myelination is generally seen as enhancing the rate of conduction of nerve fibers. LeVail and Stryker ('76) and Wolff ('81) propose that myelination has an effect on the probability of plastic changes. With increasing myelination less space is available for outgrowh of new presynaptic elements, as they can only develop where fibers are unmyelinated (Saito, '79).

Thus, myelination might be a crucial developmental step, as it determines the time when the neuronal substrate is no longer plastic (but see Jacobson, ' 80 ).

As could be expected from the behavioral data, there is a time lag between the maturation of visual and song control areas in the zebra finch brain. Visual areas attain adult morphology between day 20 and day 40, whereas song control areas continue to mature beyond day 70 . The delayed development of the song control areas can be nicely correlated with the behavioral development and reflects the need for sensory areas to mature earlier.

\section{MATERIALS AND METHODS}

Forty male zebra finches from the institute's stock were taken for this study: five birds each at ages 1, 5, 10, 20,40, 70 , and 100 days and more than 1 year. The birds were deeply anaesthetized with $0.03 \mathrm{ml}$ Nembutal (1-day-old chicks: $0.02 \mathrm{ml}$ ) and perfused via the left ventricle with a $0.9 \% \mathrm{NaCl}$ solution followed by $10 \%$ formalin in $0.9 \%$ saline. Subsequently, the brains were exposed by partly removing the brain capsule and were fixed in situ for several days.

For histological processing the brains were removed from the scull and stored in a solution of $30 \%$ sucrose in $10 \%$ formalin overnight, until the brains had sunk to the bottom of the jar. Thirty-micron serial sections were cut on a freezing microtome in either the sagittal or the transverse plane. The sections were mounted in three alternate series on gelatine-coated slides, dried on a hot plate, and processed according to three different histological protocols. Series A was stained with cresyl violet in order to show the cell bodies. Series B was processed by a modified Fink-Heimer silver impregnation (M. Konishi, personal communication) for demonstration of fiber development (the data are not presented here). Series $\mathrm{C}$ was stained according to the protocol of Gallyas ('79). This method selectively impregnates myelin. As a control, some of these sections were stained alternatively with Sudan black according to Lison and Dagnelle (Romeis, '68), a method that stains lipids and thus also reveals myelin. Examination of unstained sections with polarized light was also performed as a control.

From the five brains of each age group, at least three were selected for analysis of volume and neuron size. The other two brains were examined only if the results of the myelin density classification were not clear.

In Nissl-stained sections the volumes of the nuclei of the left hemisphere were estimated as follows. First, the outlines of the nuclei were drawn with a drawing tube attached to a Zeiss microscope. Next, the area was estimated by using a graphics tablet and an Apple computer. Finally, the volume was calculated by adding the areas for all sections and multiplying the sum by the distance between the individual sections $(90 \mu \mathrm{m})$. Volume measurements were not feasible for the ectostriatum, as the boundaries of this nucleus are very ill defined at least at the dorsal and lateral boundaries.

The soma size of individual neurons was defined by a cell size index. This was estimated by using a micrometer scale attached to the ocular of the microscope. The largest diameter (in $\mu \mathrm{m}$ ) and that perpendicular to it were measured and added together. This double measurement seemed to us to be a better compromise than the single measurements (e.g., the largest diameter) used in many comparable studies, as the shape of neurons varies between extremely ovoid and circular. An example of the distribution obtained by this method is shown in Figure $\mathbf{1}$ (n. rotundus distribution). The values obtained in these measurements were not cor rected for shrinkage, as this factor is rather constant for all age groups. Means of the cell size indices were tested for differences between the different ages by a two-tailed MannWhitney U-test. Differences in volumes between the age groups were tested with a two-tailed Student's t-test.

The development of myelination was estimated by subjectively grading the observed densities into five classes. Class 1 was chosen if not more than about five fibers could be observed in a section: class five was chosen if the density of fibers was adultlike. As our goal was not to count absolute densities, but rather to compare the extent of myelination to the adult value; this method was sufficient to demonstrate the time course of development.

\section{RESULTS \\ Nucleus rotundus}

Estimates of the mean volume are graphed in Figure 3a as a function of postnatal age. Nucleus rotundus can be distinguished from the surrounding tissue from the first day of life. The volume of this nucleus is large $\left(0.081 \mathrm{~mm}^{3}\right)$, even at this early state of development. Between day 1 and day 5 the nucleus triples in volume and reaches $71 \%$ of its 

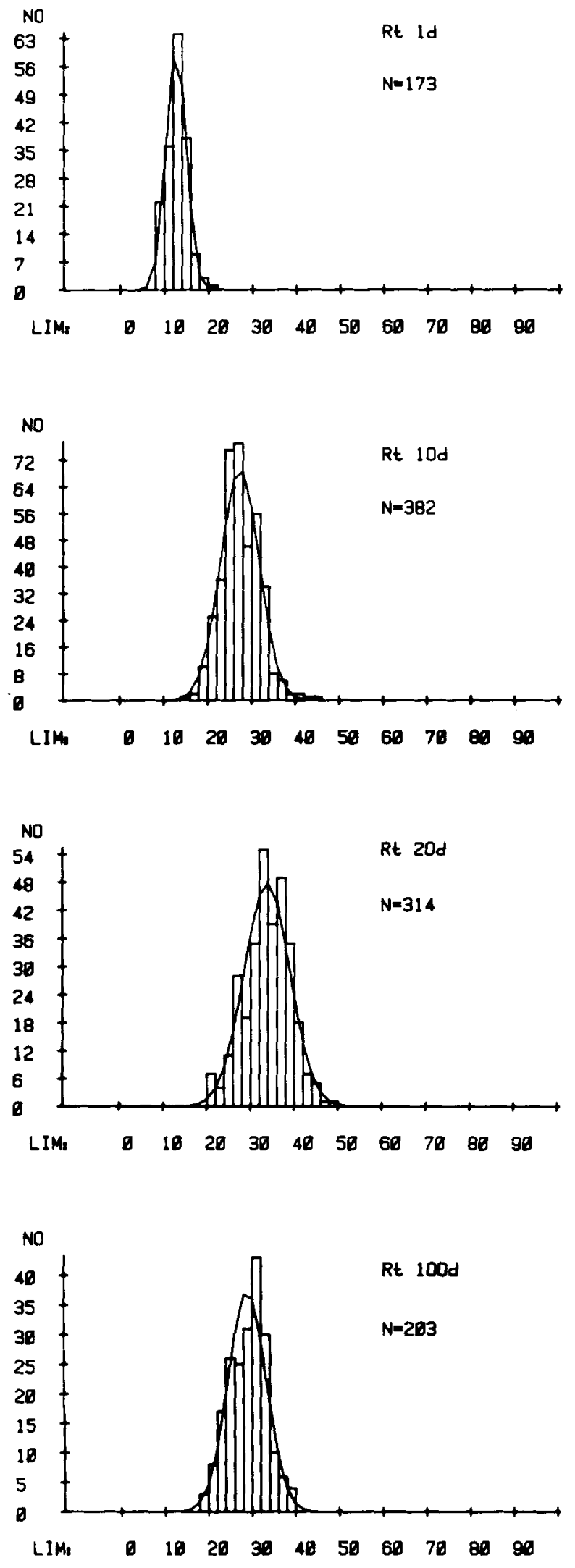

adult size. The further increase in volume at day 10 is not statistically significant. From day 10 to day 20, however, the volume increases to a value of $0.450 \mathrm{~mm}^{3}$, a $42 \%$ increase, which is highly significant. Nucleus rotundus exhibits little growth during the next 20 days and then declines to an adult volume of about $0.4 \mathrm{~mm}^{3}$. In contrast to the increase during the first 20 days, neither the growth in the second 20 days nor the decrease from day 40 to day 70 are significant (Table 1). However, a comparison of 20 or 40-day values with those of birds older than 70 days shows a significant decline.

The development of neuron size shows a pattern similar to that observed in volume growth: there is a marked increase in rotundal cell size from day 1 to day 20 (12.67 to 33.74), which can be seen in Figure 1 and Figure 3b. From day 20 to day 40 the mean neuron size declines slightly (about $11 \%$ ). The mean cell sizes expressed as percentages of the adult value are $42.7 \%$ at 1 day, $69.7 \%$ at 5 day, $91.8 \%$ at 10 day, and $113.6 \%$ at day 20 . After day 40 rotundal cell size remains constant (30.0) (Table 2).

The first myelinated axons in nucleus rotundus can be observed in 10-day-old brains (class 1). From this age, the number of stained fibers increases greatly. The myelin density of the 20-day-old rotundus corresponds to class 3 , and the adult myelin pattern (class 5) is achieved at 40 days. The data are presented graphically in Figure $3 \mathrm{c}$ and anatomically in Figure 2c-e.

\section{Ectostriatum}

The volume of this nucleus was not calculated, as its lateral and dorsal borders are not clear-cut, at least in younger animals. For the estimation of cell size and myelination we concentrated on the ectostriatal core region (Karten and Hodos, '70). In two 1-day-old brains it was difficult to distinguish between neurons and glia: nearly all ectostriatal cells were spherical with two or more nucleoli (Fig. 7a). In two other brains, however, cells could easily be identified as neurons or glia. Thus, differentiation from immature to mature ectostriatal neurons apparently takes place in the first day of life. The difficulty in separating neurons and glia may be the reason for the relatively large variance in the measurements of 1-day-old brains (Fig. 4b). By day 10 ectostriatal neurons have nearly doubled in size (Fig. 7c) and they continue to grow a further $20 \%$ between day 10 and day 20 (Fig. 7d). At this age a peak in cell size is achieved, which lies $18 \%$ above the adult value. After day 20 ectostriatal neuron size decreases to day 40 . This difference is significant, as are all the differences between age groups mentioned above (Table 2).

Myelin cannot be detected in the ectostriatum of 10-davold brains. However, at day 20 , myelin density has greatly increased and already reaches class 3 . Thus, myelination of ectostriatal axons starts between day 10 and day 20. As in nucleus rotundus, adult myelin density is achieved by 40 days.

Fig. 1. Development of neuron size of nucleus rotundus (Rt). Histograms of cell size distributions of 1-, 10-, 20-, and 100-day-old zebra finches. $\mathrm{Ab}$ scissa: Upper limit (LIM) of class of cell size index (in $\mu \mathrm{m}$, see text). Ordinate: Number of neurons per class. N: Number of neurons measured. Superimposed curve: Normal distribution. d, days. 
TABLE 1. Volume $\left(\mathrm{mm}^{3}\right)$ With Double Standard Deviation $(\mathrm{n}=\text { number of samples, } \mathrm{ns}=\mathrm{P}>.05[\mathrm{t} \text {-test }])^{1}$

\begin{tabular}{|c|c|c|c|c|c|c|c|c|c|}
\hline $\begin{array}{l}\text { Age } \\
\text { (days) }\end{array}$ & $\begin{array}{l}\text { Nucleus } \\
\text { rotundus }\end{array}$ & $\mathrm{N}$ & $\mathrm{P}$ & $\mathrm{RA}$ & $\mathrm{N}$ & $P$ & $\mathrm{HVc}$ & $\mathrm{N}$ & $\mathrm{P}$ \\
\hline 1 & $0.081 \pm 0.015$ & 4 & .001 & & & & & & \\
\hline 5 & $0.282 \pm 0.027$ & 4 & NS & $0.022 \pm 0.001$ & 2 & .03 & & & \\
\hline 10 & $0.316 \pm 0.060$ & 4 & .004 & $0.043 \pm 0.011$ & 4 & .009 & $0.038 \pm 0.005$ & 3 & .000 \\
\hline 20 & $0.450 \pm 0.050$ & 5 & NS & $0.086 \pm 0.028$ & 8 & .001 & $0.119 \pm 0.021$ & 5 & .000 \\
\hline 40 & $0.489 \pm 0.079$ & 5 & NS & $0.185 \pm 0.040$ & 5 & .008 & $0.243 \pm 0.042$ & 4 & NS \\
\hline 70 & $0.430 \pm 0.063$ & 5 & NS & $0.290 \pm 0.059$ & 4 & .05 & $0.257 \pm 0.059$ & 4 & NS \\
\hline $\begin{array}{l}100 \\
>365\end{array}$ & $\begin{array}{l}0.394 \pm 0.074 \\
0.397 \pm 0.004\end{array}$ & 3 & NS & $\begin{array}{l}0.198 \pm 0.061 \\
0.207 \pm 0.010\end{array}$ & 3 & NS & $\begin{array}{l}0.261 \pm 0.005 \\
0.267 \pm 0.044\end{array}$ & 6 & NS \\
\hline
\end{tabular}

${ }^{1} \mathrm{RA}$, robustus archistriatalis; HVc, hyperstriatum ventrale pars candale; NS, not significant.

TABLE 2. Cell Size Index (See Text) With Double Standard Deviation ( $\mathrm{n}=$ number of neurons $/$ number of animals, ns $=\mathrm{P}>.095$ (U)-test $)$

\begin{tabular}{|c|c|c|c|c|c|c|c|c|c|c|c|c|}
\hline $\begin{array}{l}\text { Age } \\
\text { (days) }\end{array}$ & $\begin{array}{l}\text { Nucleus } \\
\text { rotundus }\end{array}$ & $N$ & $\mathrm{P}$ & Ectostriatum & $\mathrm{N}$ & $P$ & RA & $\mathrm{N}$ & $\mathrm{P}$ & $\mathrm{HVc}$ & $\mathrm{N}$ & $\mathrm{P}$ \\
\hline 1 & $12.67 \pm 2.27$ & $173 / 3$ & & $11.12 \pm 2.50$ & $216 / 4$ & & & & & & & \\
\hline 5 & $20.72 \pm 3.34$ & $270 / 3$ & .05 & $15.28 \pm 2.91$ & $315 / 3$ & .05 & $14.22 \pm 3.38$ & $205 / 4$ & .095 & $20.72 \pm 3.81$ & $213 / 3$ & \\
\hline 10 & $27.29 \pm 4.39$ & $382 / 4$ & .025 & $20.07 \pm 2.77$ & $298 / 3$ & .05 & $17.64 \pm 3.36$ & $277 / 4$ & .025 & & & .095 \\
\hline 20 & $33.74 \pm 5.23$ & $314 / 4$ & .05 & $24.11 \pm 3.48$ & $244 / 3$ & .095 & $25.31 \pm 4.68$ & $247 / 4$ & .05 & $24.44 \pm 4.29$ & $261 / 5$ & .095 \\
\hline 40 & $29.90 \pm 5.01$ & $296 / 3$ & NS & $22.94 \pm 3.11$ & $277 / 4$ & NS & $29.69 \pm 5.16$ & $251 / 3$ & NS & $27.85 \pm 5.59$ & $251 / 3$ & NS \\
\hline 70 & $31.26 \pm 5.10$ & $274 / 3$ & .095 & $21.79 \pm 2.57$ & $193 / 3$ & NS & $29.32 \pm 5.48$ & $259 / 3$ & .095 & $25.07 \pm 5.01$ & $285 / 3$ & NS \\
\hline 100 & $28.83 \pm 4.33$ & $203 / 2$ & NS & $20.49 \pm 3.17$ & $201 / 3$ & NS & $27.12 \pm 3.90$ & $164 / 2$ & NS & $23.79 \pm 4.12$ & $174 / 2$ & NS \\
\hline$\geq 365$ & $29.79 \pm 4.48$ & $279 / 3$ & & $20.45 \pm 2.50$ & $357 / 3$ & & $27.27 \pm 4.15$ & $283 / 3$ & & $22.98 \pm 4.53$ & $203 / 3$ & \\
\hline
\end{tabular}

\section{Nucleus robustus archistriatalis (RA)}

The estimations of the total volume of the RA are plotted in Figure 5a as a function of postnatal age. The RA can be detected in Nissl-stained sections from day 5 onward. At this time its volume is about $10 \%$ of the adult value. The volume increases linearly, reaches a peak of $0.290 \mathrm{~mm}^{3}$ at day 70 (the differences between the age groups are all highly significant), and then decreases again until day 100. The shrinkage from day 70 to day 100 is about $30 \%$. $(\mathrm{P}<.05$, see Table 1$)$.

In contrast to the other nuclei investigated, the development of RA neurons shows a time course differing from that of volume development (Fig. 5b). In 5-day-old brains neurons and glia can easily be differentiated. The cell size increases by $43 \%$ from day 10 to day 20 . RA neurons grow a further $17 \%$ during the following 20 days and reach a peak in size, which remains relatively stable until day 70 . After this age neurons in RA decrease to adult values. The differences between the age groups up to day 40 as well as the decrease from day 70 to older ages is significant (Table 2 ). Thus, changes in neuron size markedly precede volume changes.

Myelin density of 20-day-old RA was judged to be class 1 . Although stained fibers were visible in only two of the five investigated brains (Fig. 5c) the other three seemed to be free of myelin. However, at day 40, myelin density had greatly increased and was categorized as class 3 . At day 70 the amount of myelinated axons is similar to that seen in adults (Fig. 2f-h).

\section{Hyperstriatum ventrale pars caudale (HVc)}

The development of the HVc is much delayed in comparison with the sensory nuclei and the RA. At day 10 the HVc could be separated from the surrounding tissue in Nisslstained sections in three brains. The volume of this nucleus is then about $14 \%$ of the adult value. Two other brains, where separation was not possible at this age, were omitted from the calculation. The obtained volume of $0.038 \mathrm{~mm}^{3}$ thus might be an overestimation, but probably a better compromise than assuming a volume of zero for those two brains. The HVc exhibits strong growth during the next 10 days, in which it attains a volume of $0.119 \mathrm{~mm}^{3}$, which represents $43 \%$ of the adult value. During the next 20 days a further increase can be detected: $91 \%$ of the adult volume is achieved by day 40 . In contrast to the increase up to day

Fig. 2. Myelin-stained sections (Gallyas method) demonstrating the different brain areas involved a: ectostriatum $(\mathrm{E}$ ) and nucleus rotundus ( $\mathrm{Rt}$ ), transverse section; b: nucleus robustus archistriatalis (RA), hyperstriatum ventrale pars caudale $(\mathrm{HVc})$, sagittal section; c-e: myelin-stained fibers in n. rotundus at different ages; $c=20$ days, $d=40$ days, $e=$ adult. $f-h$ : myelin-stained fibers in $R A$ at different ages: $f=20$ days, $g=40$ days, $\mathrm{h}=70$ days. Bars: $1 \mathrm{~mm}$ for $\mathrm{a}$ and $\mathrm{b}, 100 \mu \mathrm{m}$ for $\mathrm{c}-\mathrm{h}$. 

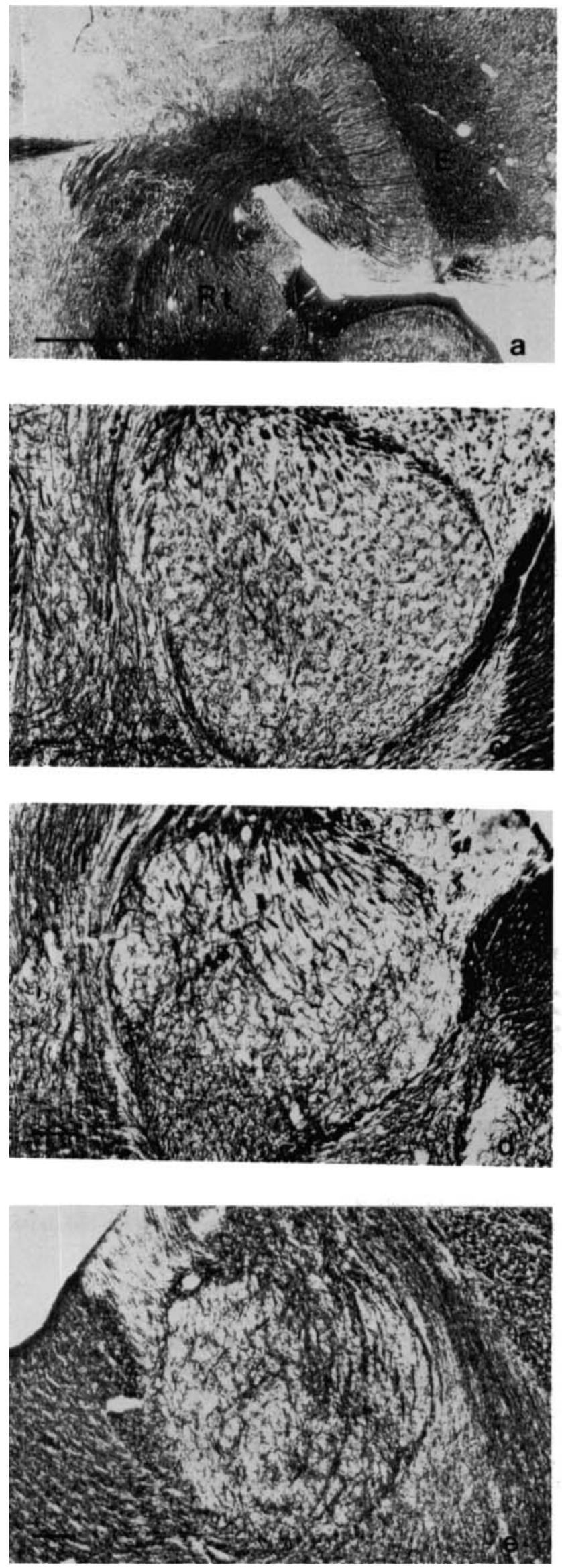
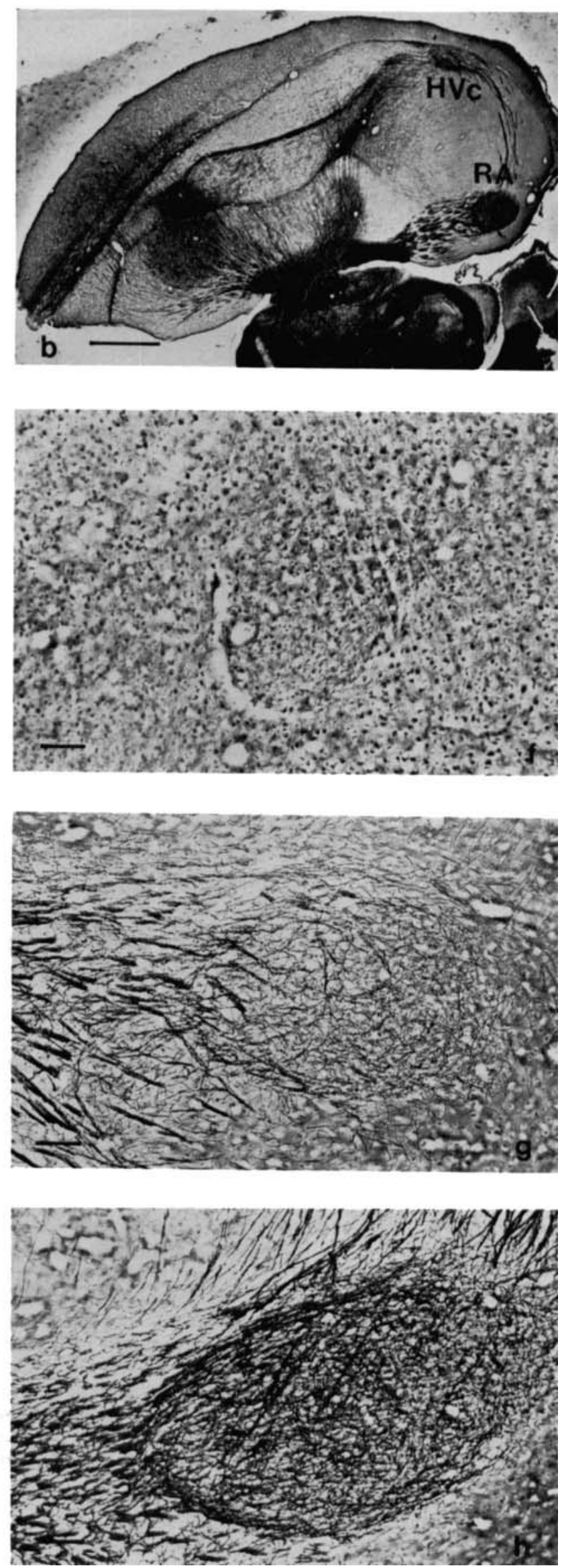

Figure 2 

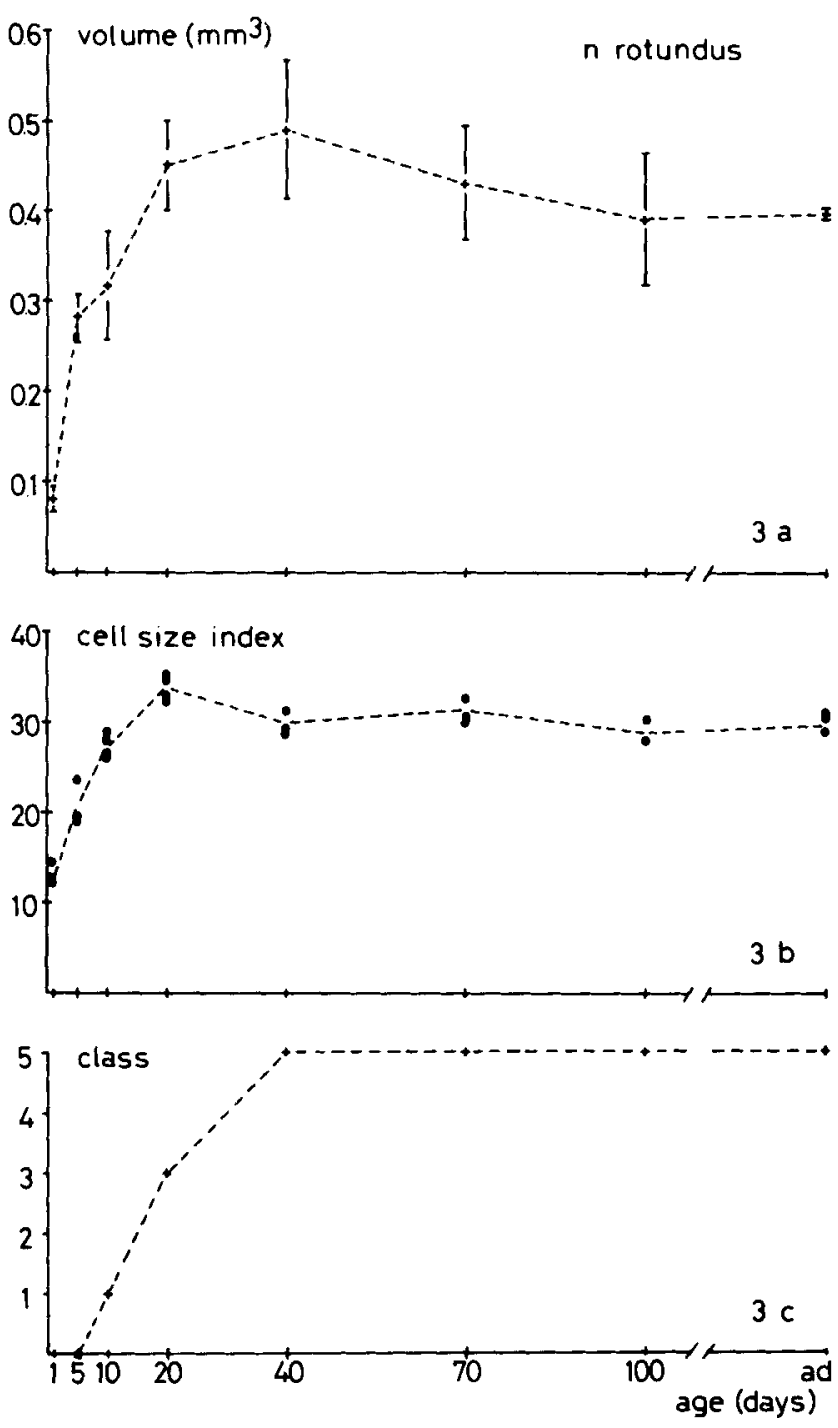

Figure 3

40 , the further increase measured at day 70 is not statistically significant. A decrease to an adult value, as seen in all other investigated areas, was not seen in the HVc (Fig. $6 a$, Table 1). As this nucleus cannot be identified clearly before day 10 , no earlier measurements of cell size could be carried out. At day 10 the cell size index is already very high (20.72). Thus, little additional growth occurs in the next 20 days. At day 40 the value is about $20 \%$ greater than the adult level. As the graph in Figure $6 \mathrm{~b}$ indicates, we observed a subsequent reduction in cell size, which continued for all age groups studied. However, the gradual decrease in neuron size was statistically not significant (Table 2). Some authors state that there might be a hemispheric asymmetry in the HVc (Nottebohm, '77). Therefore, we additionally measured the volume of the right $\mathrm{HVc}$ in one or two brains of each age group. Although we found small differences between hemispheres, they were not consistent and not statistically significant, if the data of all age groups were pooled. not investigated
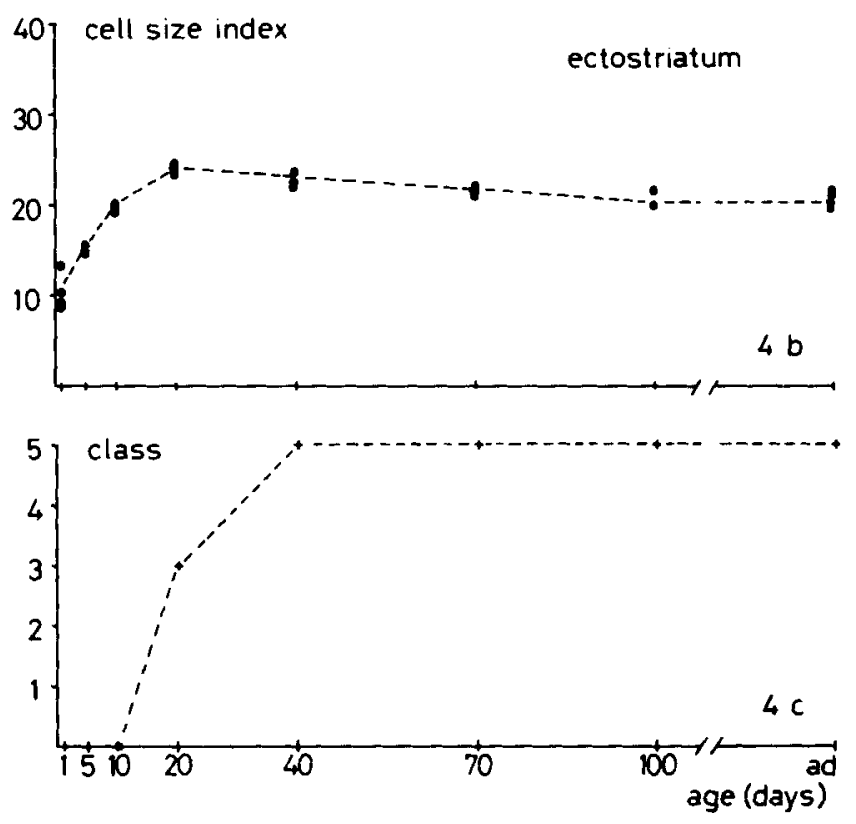

Figs. 3-6. Development of nucleus rotundus (Fig. 3), ectostriatum (Fig. 4), RA (Fig. 5), and HVc (Fig. 6). a. Volume of the nucleus $\left(\mathrm{mm}^{3}\right)$. b. Neuron size (cell size index, $\mu \mathrm{m}$ ): each point represents the mean of $50-100$ neurons per animal; the dotted line connects the means for each group. c. Myelination (note: classes are ordinate, not interval values). Abscissa: Age in days from hatching. a, Values with double standard deviation.

Myelination of axons in the HVe starts between day 20 and 40 . At day 40 only a few myelinated fibers (class 1 ) can be observed. At 70 days of age myelin density is already very similar to that seen in adults; it was designated as class 4 . The adult myelin pattern is achieved by 100 days (Fig. 6c).

\section{DISCUSSION}

In the following discussion we would like to concentrate on two topics: the correlation between brain and behavioral development and the "peak decline trend" (Murphy, '84).

Our results clearly show that there is a long delay between the maturation of the visual and the song control regions. This delay is reflected in all parameters investigated here: volume, neuron size, and myelination. Whereas 

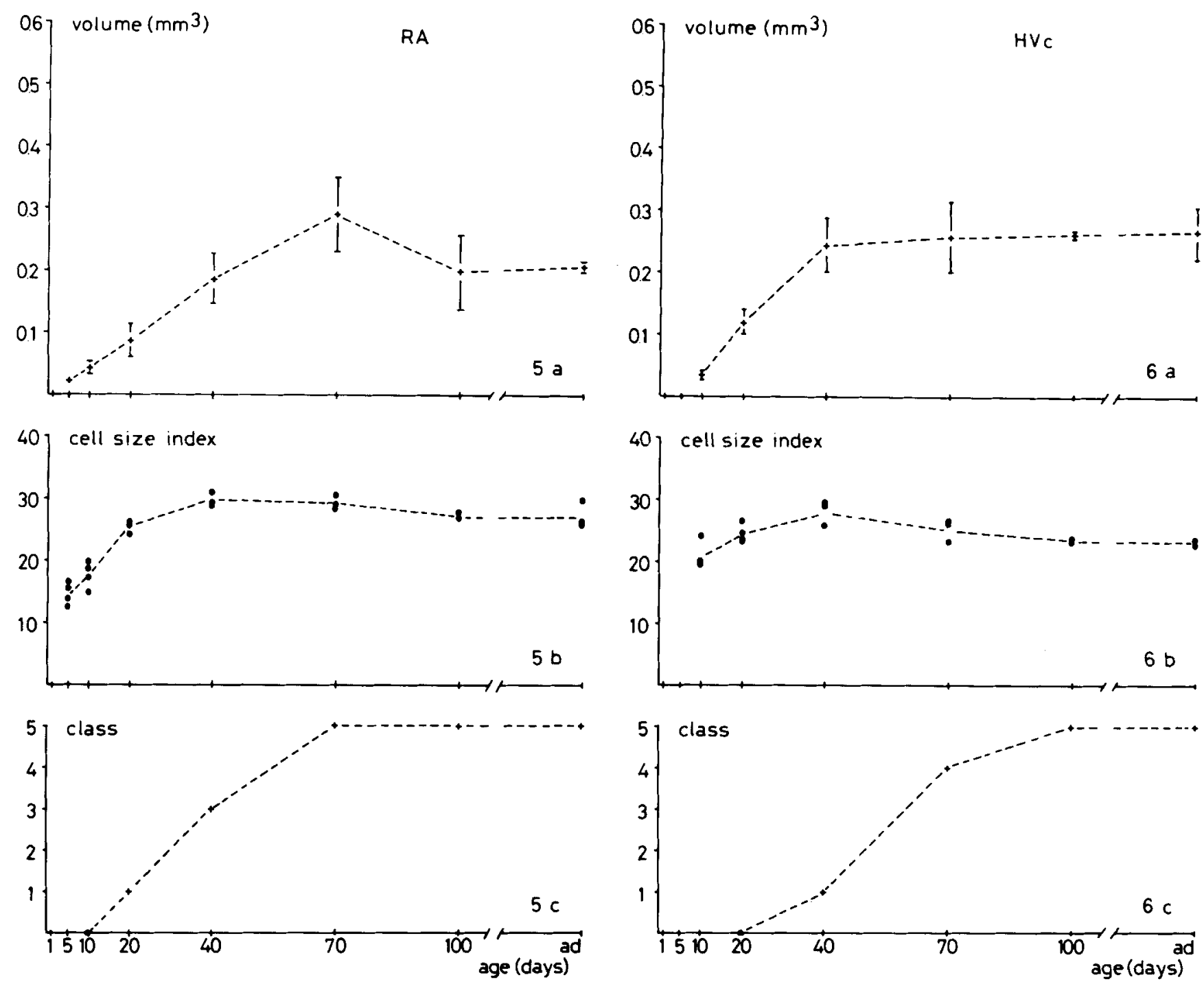

Figure 5

Figure 6

in nucleus rotundus and ectostriatum the size of single neurons and the volume of the nucleus reach a peak by 20 days (rotundus volume remains greater than in the adult until day 40), in the RA and HVc cellular and volume growth continues until day 40 . Myelination is completed by day 40 in visual areas but only at day 70 and day 100 within the RA and $\mathrm{HVc}$, respectively. These results concerning myelination are consistent with the findings of Schifferli ('48) in the starling. If, as suggested above, the functioning of a nucleus is dependent on its maturation, one should find similar differences in the time of development of visual performance and song production in the zebra finch. Indeed, a similar delay between these two behavioral categories can be demonstrated: a recent study of Bischof and Lassek ('85) revealed that important aspects of the development of visual performance occur between day 5 , when the birds open their eyes, and day 15 . At day 10 the birds react for the first time to visual stimuli with gaping, and from day 15 they are able to distinguish their parents from stuffed dummies. At day 20, the young zebra finches usually leave the next. From that day on, the birds

have to perform many behavioral acts, e.g., jumping, flying, feeding, which strongly depend on a fully functional visual system. That does not exclude that a refinement of visual performance, together with further developent of the visual system, occurs later. This further development, however, is not so conspicuous as to be detected easily. No data on fine visual discrimination ability are available so far.

Learning to sing is markedly delayed in the zebra finch. The birds produce the first song elements at about day 30 (Immelmann, '69a). Up to this age a large amount of the cellular development in the RA and HVc takes place. The earliest crystallized song appears at day 70. During the time between the first occurrence of song and crystallization, the myelination of the $\mathrm{RA}$ and $\mathrm{HVc}$ is very rapid. Moreover, the frequency of song uttered at different ages nicely coincides with the volume of the RA: young zebra finches sing more often at day 70 than at earlier or later ages (Böhner, personal communication). The late decline of RA volume occurs at a time when sensory learning of song syllables is virtually complete. Thus, this decline is unlikely to be related to sensory learning, but might be inter- 

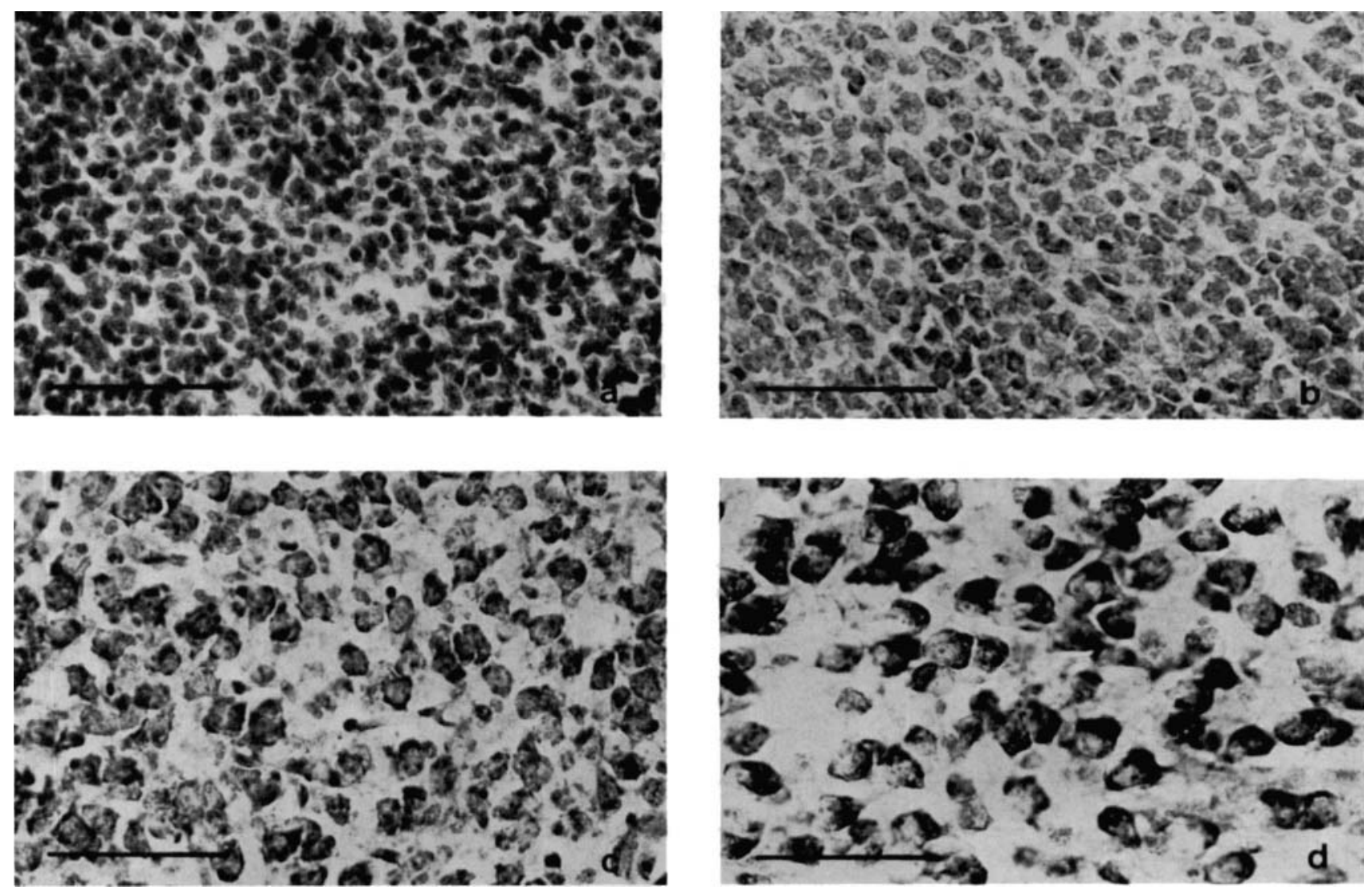

Fig. 7. Nissl-stained neurons in ectostriatum of different ages. a, 1 day; b, 5 days; c, 10 days; $d, 20$ days. Bar $=50 \mu \mathrm{m}$.

preted as a correlate for functional stabilization of the motor program.

The RA development and HVc development are different in two aspects; e.g., myelination is faster in the RA, whereas the $\mathrm{HVc}$ reaches adult volume earlier than the RA. This fits well with data of Konishi and Akutagawa ('85) and Bottjer et al. ('85), who suggested that the development of the RA may depend on the development of the HVc and vice versa. According to this speculation, the development of the RA has to have reached a certain developmental state before this nucleus is innervated by HVc efferents on day 35. As a consequence of this innervation, the RA might attain additional growth, Our data confirm this idea. At any rate, in both the visual and the song control system a correlation between the ontogeny of the brain areas involved in behavioral performance and the behavior itself can be demonstrated.

Given the functional importance of the visual system even in young birds, it is not surprising that the visual system should develop earlier than the song system, which has to be used much later. At the latest the visual system must be ready to process the incoming information at the time when the birds leave the nest. Song, however, is not needed until the birds are sexually mature.

A second general result of our study is that in nearly all brain regions, volume and neuron size first increase to values greater than those observed in adults, and then decrease to the adult values. This so-called "peak-decline trend" (Murphy, '84) has been described for features like development of spines (Boothe et al., '79; Juraska and Fifkova, '79; Murphy, '84; Garey and Saini, '81; Rausch and Scheich, '81) and development of synapses (Purves and Lichtman, '80; Winfield, '83). The peak may be explained by some sort of overproduction of neuronal connections. The decrease to adult values may be due to a selection process, which stabilizes functional synapses and eliminates those connections that fail to function when the input from the environment gains access to the given brain area (LeVail and Stryker, '79; Changeux and Danchin, '76; Wolff, '81). In this context, myelination may be seen as a process that stabilizes the given neuronal network by decreasing the probability of outgrowth of new spines and construction of new synaptic connections (LeVay and Stryker, '79; Wolff, '81). According to this scheme, the absence of a decrease in $\mathrm{HVc}$ volume is difficult to interpret. One clue may be the late beginning of myelination. It might be that this nucleus remains in a quasi-embryonic state for a long time, perhaps even during adulthood. Nottebohm and Kasparian (cf. Nottebohm, unpublished results) demonstrated that in adult zebra finch males new neurons proliferate, so that there is always a pool of small new neurons. However, as mentioned above, a similarity between the growth peak and decline in the RA and the behavior probably controlled by this nucleus can be demonstrated: the volume roughly coincides with the frequency of song. A similar increase and decrease were mentioned by Marler and Peters ('82) for the produc- 


\section{DEVELOPMENT OF THE ZEBRA FINCH BRAIN}

tion of song syllables in song sparrows: the birds sang the largest amount of different song types at the time of song crystallization, not as adults.

In summary, we have demonstrated that there are strong correlations between the development of a given behavior and the neuronal structures that are involved in the control of this behavior. In addition, we have added evidence that the so-called peak-decline trend may be a general phenomenon of development, not only occurring in mammals, but also in birds.

\section{ACKNOWLEDGMENTS}

Our thanks are due to Mrs. E. Geißler for preparing the figures, to Dr. J. Dean for improving the English manuscript, and to an anonymous referee for useful comments.

This work was supported by the Deutsche Forschungsgemeinschaft ( $\mathrm{Bi}$ 245/2) and a grant from the Minister für Wissenschaft und Forschung des Landes NordrheinWestfalen.

\section{LITERATURE CITED}

Benowitz, L.I., and H.J. Karten (1976) Organization of the tectofugal pathway in the pigeon: A retrograde transport study. J. comp. Neurol. $167: 503-520$.

Bischof, H.-J., and R. Lassek (1985) The gaping reaction and the development of fear in young zebra finches ('Taeniopygia guttata castanotis), Z Tierpsychol. 69:55-65.

Böhner, J. (1983) Song learning in the Zebra finch (Taeniopygia guttata). Selectivity in the choice of tutor and accuracy of song copies, Anim Behav. 31:231-237.

Boothe, R.G., W.T. Greenough, J.S. Lund, and K. Wrege (1979) A quantita tive investigation of spine and dendrite development of neurons in the visual cortex (area 17) of Macaca nemestrina monkeys. J. Comp. Neurol. 186:473-490.

Battjer, S.W., E.A. Miesner, and A.P. Arnold (1984) Forebrain lesions dis rupt development but not maintenance of song in passerine birds. Science 224:901-903.

Bottjer, S.W., S.L. Glaessner, and A.P. Arnold (1985) Ontogeny of brain nuclei controlling song learning and behavior. J. Neurosci. 5:1556-1562.

Changeux, J.-P., and A. Danchin (1976) Selective stabilization of developing synapses as a mechanism for the specification of neuronal networks. Nature 264:705-712.

Gallyas, F. (1979) Silver staining of myelin by means of physical development. Neurol. Res. 1:203-209.

Garey, L.J., and K.D. Saini (1981) Golgi studies of the normal development of neurons in the lateral geniculate nucleus of monkey. Exp. Brain Res. $44: 117-128$.

Guillery, R.W. (1972) Binocular competition in the control of geniculate cell growth. J. Comp. Neurol. 149:423-438.

Guillery, R.W., and D.J, Stelzner (1970) The differential effects of unilateral lid closure upon the monocular and binocular segments of the dorsal lateral geniculate nucleus in the cat. J. Comp. Neurol. 139:413-422.

Immelmann, K. (1969a) Song development in the zebra finch and other estrildid finches. In R.A. Hinde (ed): Bird Vocalization. Cambridge: Cambridge University Press, pp. 61-74.

Immelmann, K. (1969b) Über den Einfluss Frühkindlicher Erfahrung auf die geschlechtliche Objektfixierung bei Estrildiden. Z. Tierpsychol. 26:677-691

Jacobson, M. (1980) Developmental Neurobiology. Plenum Press: New York, London, 2nd edition. pp. 562.

Juraska, J.M., and E. Fifkova (1979) A Golgi study of the early postnatal development of the visual cortex of the hooded rat. J. Comp. Neurol. 183:247.

Karten, H.J., and A.M. Revzin (1966) The afferent connections of the nucleus rotundus in the pigeon. Brain Res. 2:368-377.
Karten, H.J., and W. Hodos (1970) Telencephalic projections of the nucleus rotundus in the pigeon (Columba livia). J. Comp. Neurol. 140:35-52.

Konishi, M. (1965) The role of auditory feedback in the control of vocalization in the white crowned sparrow. Z. Tierpsychol. 22:770-783.

Konishi, M., and E. Akutagawa (1985) Neural growth, atrophy and death in a sexually dimorphic song nucleus in the zebra finch brain. Nature 315:145-147.

Kroodsma, D. (1981) Ontogeny of bird song. In K. Immelmann, G.W. Barlow, L. Petrinovich, and M. Main (eds): Behavioral Development, The Bielefeld Interdisciplinary Project. New York: Cambridge University Press, pp, 518-532.

LeVay, S., and M.D. Stryker (1979) The development of ocular dominance columns in the cat. In J.A. Ferrendelli (ed); Society for Neuroscience Symposia IV, Aspects of Developmental Neurobiology, Soc. Neuroscience, Bethesda: pp. 83-98

Marler, P., and S. Peters (1982) Developmental overproduction and selective attrition: New processes in the epigenesis of bird song. Dev. Psychobiol. 15:369-378.

Murphy, E.H. (1984) Critical periods and the development of the rabbit visual cortex. In J. Stone, B. Dreher, and D.H. Rapaport (eds): Development of the Visual Pathways in Mammals. New York: Alan R. Liss, Inc. pp. 439-462.

Nixdorf, B.E., and H.-J. Bischof (1982) Afferent connections of the ectostriatum and visual wulst in the zebra finch (Taeniopygia guttata castanotis Gould)-an HRP study. Brain Res. 248:9-17.

Nottebohm, F. (1977) Asymmetries in neural control of vocalization in the canary. In S. Hanard, R.W. Doty, L. Goldstein, J. James, and G. Krauthammer (eds): Lateralization in the Nervous System. New York: Academic Press, pp. 23-44.

Nottebohm, F. (1980) Brain pathways for vocal learning in birds: A review of the first ten years. Prog. Physiol. Psychol. 8:85-125.

Nottebohm, F. (1984) Birdsong as a model in which to study brain processes related to learning. Condor $86: 227-236$.

Nottebohm, F., and A.P. Arnold (1976) Sexual dimorphism in vocal control areas of the songbird brain. Science 214:211-213.

Nottebohm, F., T.M. Stokes, and C.M. Leonard (1976) Central control of song in the canary, Serinus canarius. J. Comp. Neurol. 165:457-486.

Pettigrew, J.D. (1977) Comparison of the retinotopic organization of the visual wulst in nocturnal and diurnal raptors, with a note on the evolution of frontal vision. In S.J. Cool and E.L. Smith III (eds): Frontiers in Visual Science. New York, Heidelberg, Berlin: Springer, pp. 328-333.

Pröve, E. (1983) Hormonal correlates of behavioural development in male zebra finches. In J. Baltthazart, E. Pröve, and R. Gilles (eds): Hormones and Behaviour in Higher Vertebrates. Berlin, Heidelberg: Springer Ver lag, pp. 368-374.

Purves, D., and J.W. Lichtman (1980) Elimination of synapses in the developing nervous system. Science 210:153-157

Rausch, G., and H. Scheich (1982) Dendritic spine loss and enlargement during maturation of speech control system in the mynah bird (Gracula religiosa). Neurosci. Lett. 29:129-133.

Romeis, B. (1968) Mikroskopische Technik. München, Wien: Oldenbourg Verlag.

Saito, K. (1979) Branchings at the node of Ranvier, observed in the anterior horn and the Clarkes nucleus of the cat. Neuroscience 4:391-399.

Schifferli, A. (1948) Über Markscheidenbildung im Gehirn bei Huhn und Star. Rev. Suisse Zool. 55:118-212

Sossinka, R. (1970) Domestikationserscheinungen beim Zebrafinken Taeniopygia guttata castanotis. Zool. Jb. Syst. 97:455-521.

Thorpe, W.H. (1958) The learning of song in birds, with special reference to the song of the chaffinch Fringilla coelebs. Zool. Jb. Syst. 100:535-570.

Winfield, D.A. (1983) The postnatal development of synapses in different laminae of the visual cortex of the normal kitten and in kittens with eyelid closure. Dev. Brain Res. 9:155-169.

Wolff, JR (1981) Some morphogenetic aspects of the development of the central nervous system. In K. Immelmann, G.W. Barlow, L. Petrinovich and M. Main (eds): Behavioral Development: The Bielefield Interdisciplinary Project, Cambridge: Cambridge Univ. Press, 164-190. 